\title{
S ]ППОЛИТИЧЕСКИЕ ТЕХНОЛОГИИ
}

Карпов В.В.

\section{ПОЛИТИЧЕСКИЙ МАРКЕТИНГ - КОНЦЕПТУАЛЬНАЯ ОСНОВА ПОЛИТИЧЕСКОГО РR И РЕКЛАМЫ}

\begin{abstract}
Аннотация: Автор исходит из сложивиейся тенденции процесса принятия политических решений, которая отличается интуитивным характером, осуществляется на основе личного и профессионального опыта принимающего решение должностного лица, ичелого политического института. Скорее исключением, чем правилом, становится обращение к консультации экспертного сообщества или соверщенствование собственной профессиональной компетентности посредством получения основного или дополнительного профессионального образования. Автор статьи исходит из убеждения, что для определения сущиностного содержания политологического термина «политический маркетинг» необходимо обратиться к оценке исторических этапов его становления, а также тех концептуальных подходов, которые сопровождали этот проиесс. Предметная область статьи связана с определением содержания концеепци политического маркетинга посредством оценки его зарубежных и российских аналогов. Методология статьи основывается на системном подходе как универсальном принципе организации научного исследования, и предполагает выявление содержания и основных теорий и технологий политического маркетинга как в историческом, так и в современном политическом процессе. Научная новизна статьи, по мнению автора, заключается в оценке перспектив использования концепции политического маркетинга при анализе современных избирательных технологий, а также деятельности отдельных политических акторов в современном политическом процессе. Выявляя две ключевые разновидности концеепиий политического маркетинга, автор приходит к выводу о доминировании мобилизационной его разновидности в российском политическом пространстве, в то время как перспективы модернизационного подхода оказываются гораздо более очевидными.
\end{abstract}

Review: The author proceeds from the established tendency of the political decision-making process that has the intuitive nature and carried out on the basis of personal and professional experience of the official making the decision. Appealing to the expert community or improvement of one's own professional competence through receiving the basic o additional professional education is now rather an exception than a rule. The author of article proceeds from the belief that for definition of the term "political marketing" it is necessary to view the historical stages of the development of the term as well as conceptual approaches that accompanied that process. The scope of the article relates to defining contents of the concept of political marketing by analyzing its foreign and Russian analogues. The methodology of article is based on systems approach as a universal principle of the organization of scientific research and assumes the discovery of the contents and the main theories and technologies of political marketing both through history and in the modern political process. According to the author, the scientific novelty of the article is in assessment of the perspective use of the concept of political marketing in the analysis of modern voting technologies and also activity of certain political actors in the modern political process. Revealing two basic variants of concepts of political marketing the author comes to the conclusion about domination of its mobilization version in the Russian political space while prospects of the modernization approach are much more obvious. Ключевые слова: Политический маркетинг, Политическая реклама, Политический PR, Политический процесс, Политическая культура, Публичная власть, Политические коммуникации, Политическая модернизация, Политические технологии, Политический имидж. 


\section{Политика и общество 8 (116) • 2014}

Keywords: Political marketing, political advertising, political PR, political process,political culture, public authority, political communication, political modernization, political technologies, political image.

$\mathrm{B}$ современных условиях процесс принятия политических решений на различных уровнях публичного управления зачастую происходит интуитивно, на основе личного и профессионального опыта принимающего решение должностного лица, целого политического института. Скорее исключением, чем правилом становится обращение к консультации экспертного сообщества или совершенствование собственной профессиональной компетентности посредством получения основного или дополнительного профессионального образования. Достаточно редко органы публичной власти самостоятельно разрабатывают и реализуют собственную стратегию информационно-коммуникационной политики. Несмотря на сложившуюся тенденцию, совершенно оправданным выглядит вывод о том, что эффективность реализации политического решения существенно возрастает, если оно принято с использованием приемов и техники политического анализа и прогнозирования. На современном этапе политического развития понятие «политический маркетинг» широко используется как в научном контексте, так и в реальном политическом процессе в России и за рубежом ${ }^{1}$. Между тем, однозначного толкования данный термин в научном сообществе не получил. Основной причиной создавшейся коллизии становится наличие смежной области экономических и политологических исследований политического маркетинга.

Для определения сущностного содержания политологического термина «политический маркетинг» необходимо обратиться к оценке исторических этапов его становления, а также тех концептуальных подходов, которые сопровождали этот процесс. Оценка возможностей применения маркетинговой теории к общественным и правительственным структурам актуализируется в западной экономической науке с конца 60-х годов XX века. Так, Ф. Котлер утверждал, что цель политического маркетинга заключается в удовлетворении потребностей аудитории, под которой подразумевались ключевые политические акторы, общественно-политических ор-

1 Морозова Е.Г. Политический рынок и политический маркетинг: Концепции, модели, технологии. М., 1999. - С. 28. ганизаций, государственных учреждений, а также религиозных объединений ${ }^{2}$. Американские исследователи Р. Глик и Д. Ниммо одними из первых обратились к терминологии маркетинга, еще не до оценивая его перспективы в области политических исследований ${ }^{3}$ Прорыв в оценке значения маркетинга совершил упоминаемый выше Ф. Котлер, выведя маркетинговые теории и прикладные технологии в статус объектов научного анализа, в первую очередь, в контексте деятельности органов публичной власти и избирательных кампаний ${ }^{4}$.

В течение 60-х - 70-х гг. XX века концепция политического маркетинга получила свою дальнейшую оценку в работах социолога Пьера Бурдье, который ввел в практику политического дискурса категорию «политическое пространство». В процессе взаимодействия политических агентов друг с другом происходит формирование политического капитала ${ }^{5}$. Таким образом, по аналогии с экономическим продуктом, политический становится следствием взаимо согласованных действий политических акторов, от содержания которых зависит качество получаемого капитала (реализация политических решений).

На протяжении 70-х гг. ХX века в научной литературе обосновывается тезис о том, что теоретические принципы и прикладные технологии маркетинга можно использовать в системе государственного управления. В результате маркетинг как прикладная технология достижения прибыли при грамотной затрате имеющихся ресурсов становится частью менеджмента как науки управления. Смысловое содержание политического маркетинга видится в целенаправленном воздействии на поведение масс в условиях конкуренции политических акторов. Так, исследователь Г. Маузер

\footnotetext{
${ }^{2}$ Kotler Ph. Marketing for Non-Profit Organisations. - Englewood Cliffs, 1975. - P. 127.

${ }^{3}$ Nimmo D. The Political Persuaders. - Englewood Cliffs, 1965. - P. 83.

${ }^{4}$ Kotler Ph. Marketing for Non-Profit Organisations. - Englewood Cliffs, 1975. - P. 130.

${ }^{5}$ Бурдье П. Социология политики / Пер. с фр.; сост., общ. ред. и предисл. Н.А. Шматко. М., 1993. - С. 278.
} 
определил политический маркетинг как один из приемов менеджмента, хотя и обладающий значительно более выраженным свойством «влияния на поведение масс» ${ }^{6}$.

На протяжении последующих десятилетий проблема концептуализации политического маркетинга как самостоятельной области исследования остается актуальной в зарубежных исследованиях. Большинство созданных в рамках маркетинговой парадигмы трудов принадлежат специалистампрактикам. Достоинствами данной литературы является практико-ориентированный характер, использование конкретных ситуаций, позволяющих составить четкое представление о реальном политическом процессе ${ }^{7}$ (Д. Наполитан, Р. Агранов, Ж. Сегела, М. Бонгран и др.). Преобладание прикладных исследований в области политического маркетинга позволило сформулировать требования к эффективности избирательных кампаний по выборам в органы власти, а также высказать гипотезу о наличии прямой зависимости между используемыми приемами манипуляции сознанием избирателей и результатами предвыборной гонки.

Несмотря на очевидные достоинства, прикладные исследования были не лишены и отдельных недостатков. Отсутствие достаточного уровня теоретико-методологических знаний не позволила им, по мнению Е.Г. Морозовой, выйти на уровень концептуализации содержания и технологий политического маркетинга. Наличие серьезных трудов позволяет рассматривать политический маркетинг как единство теории и практики, как академическую и в то же время прикладную дисциплину, благодаря которой политическая область является сегодня не только искусством, но и наукой ${ }^{8}$.

В российской науке концепция политического маркетинга исследуется в работах Г. Дилигенского 9 ,

\footnotetext{
${ }^{6}$ Mauser G. Political Marketing. New York, 1983. - P. 5.

${ }^{7}$ Морозова Е.Г. Политический рынок и политический маркетинг: концепции, модели, технологии. М.: «Российская политическая энциклопедия» (РОССПЭН), 1999. - C. 57.

${ }^{8}$ Морозова Е.Г. Политический рынок и политический маркетинг: концепции, модели, технологии. М.: «Российская политическая энциклопедия» (РОССПЭН), 1999. - C. 59.

9 Дилигентский Г.Г. О политическом рынке и рациональном выборе в российских условиях // Полис. 2002. - №2.
}

Е. Морозовой ${ }^{10}$, Д. Нежданова ${ }^{11}$ и др. В работах данных авторов политический маркетинг окончательно выходит за пределы области политического PR, приобретая значение практического компонента маркетинга ${ }^{12}$. На протяжении 80-х гг. XX в. приоритет научного сообщества оказался сосредоточен на оценке практической составляющей применения концепции маркетинга при исследовании электорального поведения избирателей. По аналогии с зарубежной политологией российская в течение последних десятилетий пришла к пониманию необходимости концептуализации и моделирования политического процесса в терминологии и с использованием приемов политического маркетинга $^{13}$. В политологическом словаре В.Ф. Халипова последний понимается в качестве политической технологии, содержание которой составляют приемы и методы, воздействующие на социальные сообщества ${ }^{14}$. Аналогичное прикладное определение дает и Ф.Н. Ильясов. С его точки зрения маркетинг представляет собой субъективное свойство политического лидера, направленное на изучение особенностей электората, для получения максимально возможного количества голосов на выборах ${ }^{15}$

Следуя логике рассуждений российских и зарубежных исследований, политический маркетинг оценивается в контексте экономических категорий спроса и предложения. Областью его применения являются не только избирательные кампании, но и все пространство взаимодействия государства и об-

\footnotetext{
${ }^{10}$ Морозова Е. Г. Политический рынок и политический маркетинг: Концепции, модели, технологии. М., 1999.

${ }^{11}$ Нежданов Д. В. Политический маркетинг: вчера, сегодня, завтра. СПб., 2004.

${ }^{12}$ Покрищук Д.В. Политический маркетинг: к вопросу о некоторых аспектах российского и зарубежного опыта // Журнал научных публикаций аспирантов и докторантов. - 2008. - № 10.

${ }^{13}$ Афанасьев М.Н. Поведение избирателей и электоральная политика в России. // Полис. - 1995. - № 3; Шестопал Е.Б., Новикова-Грунд М.В. Восприятие образов двенадцати ведущих политиков России (Психологический и лингвистический анализ) // Полис. - 1996. - № 5; Шестопал Е.Б. Образ власти в России: желания и реальность (Политико-психологический анализ). // Полис. - 1995. - № 4 и др.

${ }^{14}$ Политологический словарь. / Под ред. проф. В.Ф. Халипова. - М., 1995. - С. 81.

${ }^{15}$ Ильясов Ф.Н. Политический маркетинг, или Как «продать» вождя. // Полис. - 1997. - № 5. - С. 88.
} 


\section{Политика и общество 8 (116) • 2014}

щества, всех политических акторов ${ }^{16}$. В результате, политический маркетинг реализуется в качестве основной теории регулирования поведенческой модели голосования, ориентированной на предсказание электорального поведения избирательного корпуса, что полностью укладывается в классическую прикладную модель, сформулированную на рубеже 70 - 80-х гг. ХХ в. в зарубежной исследовательской традиции. Маркетинговый подход в политическом контексте продолжает оцениваться в рамках процесса создания экономических стимулов для повышения электоральной активности масс и снижения элемента случайности в результатах голосования ${ }^{17}$.

Продолжительное отсутствие исследований политического маркетинга в России обусловлено ограниченностью практики проведения избирательных компаний на всех уровнях публичной власти. Политический маркетинг изначально воспринимался в качестве прикладного, утилитарного комплекса мер и решений, направленных на достижение победы в избирательной кампании. Таким образом, в основе этой концепции длительное время видели своеобразную систему оптимизации значимых характеристик кандидата и информационного воздействия на целевую аудиторию $^{18}$, целью которой было получение максимального количества голосов на выборах.

В последующей политической практике социологическая модель поведения избирателей (пропорциональная зависимость количества голосов и принадлежности к определенной социальной страте) постепенно вытесняется инструментами политического маркетинга ${ }^{19}$. Правление посредством репрезентаций становится устойчивым стереотипом поведения носителей политической власти. Репрезентации рассматривались в качестве проекции на общественное сознание представлений о политической жизни, задачей которой становилось предсказание реакции избирательного корпуса в пери-

\footnotetext{
${ }^{16}$ Lindon D., Weill P. Le choix d'un depute. Un modele explicatif du cornportement electoral. - Paris, 1974. - P. 7.

${ }^{17}$ Медеуова Д.Т. Общие подходы и специфика политического маркетинга / Д.Т. Медеуова. - М.: Институт научной информации по общественным наукам, 2010. - С. 153.

${ }^{18}$ Ильясов Ф. Н. Политический маркетинг, или Как «продать» вождя // Полис. 1997. - №5. - С. 17.

${ }^{19}$ Пшизова С. И. Демократия и политический рынок в сравнительной перспективе // Полис. 2000. - №2. - С. 26.
}

од выборов на ту или иную партию или кандидата. Фактически, речь шла о выстраивании новой модели диалога общества и власти, где регулирующее воздействие со стороны политических технологий становилось необходимым ${ }^{20}$. Подобные убеждения приводят к тому, что политические акторы начинают производить необходимый покупателю (населению) политический продукт, способствуя снижению социальной напряженности и удовлетворению потребностей электората. Политическая культура также стремительно меняется, заставляя публичную власть не только признать гражданское общество в качестве равноправного субъекта, но и координировать структуру взаимодействия с ним.

Таким образом, можно сделать вывод о том, что в России доминирует принцип самоорганизации политического пространства, который обеспечивает возможность реализации маркетинговой деятельности акторов политики, но только при условии владения ими приемами и технологиями последней. Это обусловливает специфику политического маркетинга на российском политическом пространстве, которая выражается в том, что зачастую его использование происходит на фоне недостаточно свободного участия политических акторов в конкурентной борьбе, когда привлекательность для избирателей политического продукта того или иного актора, не обеспечивает победы в политической кампании.

Российский политический маркетинг можно отнести к мобилизационному, поскольку он направлен на то, чтобы быстро и эффективно мобилизовать поддержку общества для достижения поставленных целей посредством использования средств коммуникации. Цели политического маркетинга формулируются исходя из сложившейся расстановки сил в политических элитах, а не реальных запросов граждан ${ }^{21}$. В случае доминирования мобилизационного подхода механизмы получения «обратной связи» от общества либо просто отсутствуют, либо симулируются, но зачастую используются только для того, чтобы скорректировать тактические механизмы мобилизации, но не влияют на ее стратегические цели. В результате в общественном сознании возникает ощущение, что публичная власть не владеет всей полнотой информации

\footnotetext{
${ }^{20}$ Нежданов Д.В. Политический маркетинг: вчера, сегодня, завтра. СПб., 2004. - С. 10.

${ }^{21}$ Недяк И.Л. Политический маркетинг: Основы теории. М., 2008. - C. 72.
} 
Политические технологии

о реальной ситуации в обществе, поскольку находится на значительном удалении от него 22 .

В результате реализации модели мобилизационного маркетинга формируются следующие последствия ее применения: агрессивная стратегия, снижение уровня доверия к политическим партиям, отчуждение граждан от политики, демассификация партий, снижение уровня доверия к институту выборов и т.д. ${ }^{23}$ ». Проявления процесса потдемократии также есть следствие применения модели мобилизационного маркетинга ${ }^{24}$.

В отличие от российской практики, мировая строится на приоритете стратегического планирования над тактическим, в процессе реализации технологий политического маркетинга. Основная задача заключается не в производстве необходимого обществу политического продукта, а в формировании доверия к политическим институтам. Политический маркетинг приобретает модернизационные свойства, поскольку ориентирован на постоянную модернизацию политических отношений, государство и общество выступают в качестве равноправных партнеров для создания долгосрочных, доверительных отношений ${ }^{25}$. Цели политического маркетинга при модернизационном подходе формируются на основе реальных общественных запросов, на которые публичная власть обязана отреагировать, а не зацикливаться на проблемах взаимоотношений политических элит. Реальная, эффективная «обратная связь» во взаимоотношениях с ключевыми политическими акторами становится непременным условием успеха любого политического решения ${ }^{26}$.

${ }_{22}^{2}$ Фурман Д., Морозов А., Коргунюк Ю., Блюм А. Политическая система России после путинских реформ [Электронный ресурс] // [Режим доступа]: URL: http://www.polit.ru/ research/2005/01/27/ polit_system.html (Дата обращения: 01.08.2013)

${ }^{23}$ Недяк И.Л. Актуальность применения метафоры политического маркетинга для изучения и прогнозирования политического процесса [Электронный ресурс] // [Режим доступа]: URL: http://www.strategy-spb.ru/partner/files/nedyak.pdf (Дата обращения: 02.08.2013)

${ }^{24}$ Crouch C. Post-democracy / C. Crouch [Электронный peсурс] // [Режим доступа]: URL: http://ww.kreisky-forum.org/ pdfs/2009/2009_03_05.pdf (Дата обращения: 24.09.2012).

${ }^{25}$ Hennenberg S. Political Marketing Theory: Hendiadyoin or Oxymoron // Working Paper Series, University of Bath, 2004. - P. 21.

${ }^{26}$ Ragsdale L. Strong feelings: emotional responsness to presidents. // Political Behavior. - V. 13. - № 1. - 1991. - P. 33 - 59.
Объективным препятствием на пути перехода к модернизационной парадигме выступает способность существующих институтов политической коммуникации (средства массовой информации, политические партии, общественные организации) реализовывать функцию обеспечения информационной мобилизации, но не являться средствами сетевого взаимодействия между публичной властью и обществом. Каналы политических коммуникаций централизованы и направлены в одном направлении: от власти к обществу, обратные связи либо подавляются органами публичной власти, либо преломляются в удобном для информационной мобилизации формате ${ }^{27}$.

Основополагающий постулат модернизационной теории политического маркетинга, распространенный в зарубежной практике, заключается в том, чтo public policy (публичная политика) в долгосрочной перспективе может быть эффективна только при наличии реальных механизмов получения ответной (прямой) реакции от общества и корректировке, исходя из нее стратегических целей внутренней и внешней политики. В рамках данного подхода политический маркетинг оценивается не как электоральная технология, а как часть прикладной политологии, то есть науки о процессе принятии политических решений. При этом политический маркетинг обладает свойством повышения значения прикладной политологии, поскольку является методологически интегрированным, то есть его инструментарий находится в смежной области нескольких дисциплин - маркетинга, менеджмента, фундаментальной политологии и пр. ${ }^{28}$

Исходя из вышеизложенного, возможно сформулировать главную задачу политического маркетинга в России - интеграция потребностей, интересов гражданского общества и публичной власти через создание поля их сетевого взаимодействия. Это означает переход политического маркетинга из мобилизационной формы к модернизационной. Суть, которой для России заключается в стремле-

\footnotetext{
${ }^{27}$ Lipman M. Media Manipulation and Political Control in Russia [Электронный ресурс] // [Режим доступа]: URL: http://www. chathamhouse.org.uk/publications/papers/view/-/id/698/ (Дата обращения: 03.08.2013).

28 Markus Karp, Udo Zolleis Politisches Markting: eine Einfuhrung in das Politisches Marktingmit aktuellen Bezugen aus Wissenschaft und Praxis. Baden-Baden. 2004. - P. 184.
} 


\section{Политика и общество 8 (116) • 2014}

нии гражданского общества активно участвовать в политических процессах, влиять на процесс принятия политических решений.

Поскольку модернизационная концепция политического маркетинга претендует на регулирование отношений всех политических акторов, находящихся в различных отношениях, порожденных разнонаправленностью политического процесса. Возможно, следующим образом охарактеризовать влияние политического маркетинга на политический процесс. Во-первых, последний ориентирован на анализ и прогноз состояния рынка посредством новых информационных и исследовательских технологий. Во-вторых, маркетингу присуще умение воздействовать на потребителей с помощью, главным образом, СМИ. Маркетинг в равной степени помогает всем акторам получать и интерпретировать информацию, принимать решение на основе нескольких альтернативных вариантов и нести ответственность за свой выбор. Данные принципы позволяют четко атрибутировать политический маркетинг от предшествующей политической пропаганды. Фактически, речь идет о том, что реализация модернизационной концепции политического маркетинга становится возможной только при условии развития гражданской политической культуры и высокого уровня правосознания всех политических акторов.

Ключевым элементом политического маркетинга становится исследование политического рынка через призму изучения общественного мнения, избирательная инженерия и политическая реклама как важные инструменты политической борьбы в любых общественных условиях и политических режимах. Но определяющей целью политического маркетинга становится изучение особенностей публично-властных отношений, сложившихся в обществе. Поскольку данная исследовательская цель представляется сложнореализуемой, то возникает потребность выделить ключевые объекты исследования: политическая культура, уровень развития политических структур, политическая и правящая элита, общественное сознание.

Если первые три фактора исследуют традиционными методами политического анализа, то стереотипы общественного сознания - путем изучения общественного мнения. Изучают его через косвенные средства массовой информации (документы органов власти, общественно-политических организаций), прямые (личные контакты работников органов управления с населением на собраниях, митингах, забастовках, прием граждан, переписка) и специализированные каналы поступления информации. Специализированные каналы выражения общественного мнения являются самыми надежными, поскольку с помощью социологических и социо-психологических методов позволяют получать репрезентативную информацию по широкому кругу вопросов. Они доминируют в политическом маркетинге.

Поскольку под «политическим маркетингом» мы понимаем совокупность форм, методов и технологий исследования, проектирование, регулирования и внедрения в общественно-политическую практику определенных установок общественного сознания с целью завоевания и удержания контроля над рынком публичной власти, поэтому цели маркетинга в государственном управлении также трансформируются. Во-первых, коррекция поведенческих моделей, сформировавшихся у определенных социальных групп и представляющих угрозу для сообщества в целом (различные формы девиантного поведения). Во-вторых, внедрение в социальную практику идей, ценностей, поведенческих алгоритмов, рассматриваемых обществом как положительные (гражданственность, политическое участие, политическая лабильность и т.д. $)^{29}$. В-третьих, оказание методологической поддержки процессу реформирования государственного управления.

Создавая условия для реализации данных целей, политический маркетинг выступает в качестве универсальной управленческой технологии, приобретающей в то же время ярко выраженный политический смысл и демократическую направленность. Особенность маркетингового подхода заключается в необходимости решения задачи управления существующим рынком, а значит, сближения интересов и потребностей власти и общества. Представляя собой технологию политического управления, маркетинг сосуществует с другими современными технологиями - «PR», политической рекламой и т.д. Для определения сущностных свойств политического маркетинга необходимо обозначить его смежные области с такими технологиями как политическая реклама и PR.

${ }^{29}$ Козлов С.В. Политический маркетинг: учебное пособие / С.В. Козлов. - Новосибирск: СибАГС, 2008. - С. 85. 
Политическая реклама становится необходимым элементов современного постдемократического политического процесса. Ее основное назначение заключается в выяснении психологии потребителей, его субъективных интересов и потребностей ${ }^{30}$. В современной политической науке существует значительное количество определений политической рекламы. Исследователь Е.В. Егорова-Гантман определяет политическую рекламу как коммуникативную технологию, реализуемую посредством СМИ и влияющую на общественное мнение в отношении политического процесса. При этом, политический процесс оценивается как сетевая коммуникация субъектов и объектов. Последними могут стать программы, политические события, документы, бюджет. Взаимосвязанными с политической рекламой становятся понятия «политическая программа», «политический имидж», «политические идеи» ${ }^{31}$. И.И. Скрипюк сближает содержание политической рекламы с политическим маркетингом, полагая, что реклама информирует потребителя о продукте (кандидате), создает его имидж и оплачивается рекламодателями по установленным тарифам $^{32}$. С.Ф. Лисовский также склоняется к мысли, что политическая реклама относится к форме политической коммуникации, обеспечивающей адресное воздействие на общественное мнение, отличительным свойством которой становится оригинальность, лаконичность и доступность для восприятия ${ }^{33}$. В.Г. Зазыкин отмечает, что политическая реклама направлена на оказание влияния на избирателей, т.е. изменение их установок, отношений и симпатий ${ }^{34}$.

Несмотря на все многообразие определений, большинство исследователей склоняются к мне-

\footnotetext{
${ }^{30}$ Беклешов Д.В., Самусев В.П. Реклама - ее функции, цели и методы создания. - Киев, 1974. - С. 12.

${ }^{31}$ Егорова-Гантман Е.В. Политическая реклама. - М., 2002. - C. 16.

32 Скрипюк И.И. Политическая реклама и политические PR в России // Общество и политика: Современные исследования, поиск концепций / Под ред. В.Ю. Большакова. - СПб., 2000. - C. 225.

33 Лисовский С.Ф. Политическая реклама [Электронный ресурс] / С.Ф. Лисовский. // [Режим доступа]: http:// www.advesti.ru/publish/osn/200405_polit (Дата обращения: 01.08.2013)

34 Зазыкин В.Г. Психологические аспекты избирательного процесса. - М., 2002. - С. 85 - 86.
}

нию, что политическая реклама направлена на формирование позитивного имиджа кандидата, партии, общественной организации и т.п., привлекательного и ожидаемого для общества ${ }^{35}$. Политическую рекламу можно определить как сферу двустороннего коммуникативного воздействия «производителя» и «потребителя» политических идей, направленную на создание положительно оцениваемого политического имиджа кандидата, партии и т.п. группами общественности, с целью трансформации их поведенческих установок и привлечения внимания к рекламируемому политическому «продукту» ${ }^{36}$.

Наиболее близким по содержанию к политической рекламе оказывается политический PR. Иx сближает маркетинговый характер деятельности ${ }^{37}$. B политической рекламе и $\mathrm{PR}$ основным предметом оказывается продажа товара (политического продукта). Вместе с тем PR представляет собой значительно более обширную сферу деятельности, поскольку является самостоятельной частью политического маркетинга. Напротив, политическая реклама становится частью политического PR, поскольку на конечный результат напрямую влияет объем и качество используемых средств массовой коммуникации, круг каналов коммуникации опосредующих взаимоотношения политической организации и СМИ ${ }^{38}$.

Основополагающим различием политической рекламы и политического PR выступает бесплатность последней формы политической коммуникации. Поэтому акции PR, по мнению общества, заслуживают большего доверия, чем платная политическая реклама ${ }^{39}$. В этом отношении моно согласиться с мнением С. Блэка: «PR - искусство и наука достижения гармонии посредством взаимопонимания, основанное на правде и полной

\footnotetext{
35 Чумиков А.Н., Бочаров М.П. Связи с общественностью: теория и практика. М.: Дело, 2006. С. 24 - 30; Боброва И.И. PR? Белый PR! Цветной PR: М.: Вершина, 2006. - С. 12 - 14; Связи с общественностью как социальная инженерия / Под. ред. В.А. Ачкасовой, ЈІ.В. Володиной. СПб.: Речь, 2005. C. $45-47,67$.

36 Феофанов О.А. Реклама: новые технологии в России. СПб., 2000. - С. 251.

${ }^{37}$ Коттллер Ф. Основы маркетинга. - СПб., 1994. - С. 18.

${ }^{38}$ Стровский Д.А. Реклама и паблик рилейшнз: Словарь английских терминов. - Екатеринбург, 1999. - С. 179.

${ }^{39}$ Егорова-Гантман Е.В. Политическая реклама. - М., 2002. - C. 14.
} 


\section{Политика и общество 8 (116) • 2014}

информированности» ${ }^{40}$. Но есть образцы политического PR, заведомо реализующие ложные или сомнительные идеи, но, при этом, раскрываются их недостатки и слабости. В данном случае PR сближается с политической рекламой и пропагандой, поскольку также направлен на создание политического имиджа, внедрение в общественное сознание определенных ценностей и идей ${ }^{41}$.

В научной литературе существует точка зрения, что политическая реклама представляет собой разновидность $\mathrm{PR}^{42}$. Д.А. Стровский полагает, что реклама выполняет двоякую функцию: является сферой общественной жизни и элементом $\mathrm{PR}^{43}$. Ключевым свойством политической рекламы, в отличие от PR является специфичная целевая установка процесса коммуникации. Эффективная политическая реклама направлена на увеличение деловых связей, привлечение сторонников, изменение общественного мнения в положительную сторону, а политический $\mathrm{PR}-$ на получение правдивой информации и согласования интересов участников взаимодействия ${ }^{44}$.

Сущностное значение политической рекламы не определено и в законодательстве Российской Федерации. Единственное упоминание термина содержится в Федеральном законе «О рекламе» от 13 марта 2006 г. $^{45}$, где лишь в ст. 2 указано, что действие данного закона не распространяется на политическую рекламу, в том числе предвыборную агитацию. Таким образом, будучи только упомянутой, политическая реклама отождествляется с предвыборной агитацией, причем, исходя из смысла данной нормы, политическая реклама является общей категорией, а предвыборная агитация оценивается как разновидность политической рекламы. Возможно, сделать вывод, что в контексте Федерального закона «О ре-

${ }^{40}$ Блэк С. Паблик рилейшнз. Что это такое? - М., 1990. - С. 17.

${ }^{41}$ Егорова-Гантман Е.В. Политическая реклама. - М., 2002. - C. 14.

${ }^{42}$ Блэк C. Паблик рилейшнз. Что это такое? - М., 1990. C. $30-31$.

${ }^{43}$ Стровский Д.А. Реклама и паблик рилейшнз: Словарь английских терминов. - Екатеринбург, 1999. - С. 17.

${ }_{44}$ Алтухова Н.Ю. Политический маркетинг в современной России: диссертация на соиск.степ.к.полит.н. Ставрополь, 2006. - C. 24

45 Федеральный закон от 13 марта 2006 г. № 38-Ф3 (в ред. от 12 апреля 2007 г.) «О рекламе» // Собрание законодательства РФ. 2006. № 12. Ст. 1232. кламе» любая предвыборная агитация относится к политической рекламе, однако не любая политическая реклама обязательно является предвыборной агитацией. Наличие подобной юридической коллизии, придает политической рекламе статус избирательного термина.

В соответствии с нормой ч. 4 ст. 48 Федерального закона «Об основных гарантиях избирательных прав и права на участие в референдуме граждан Российской Федерации», кандидат, избирательное объединение, инициативная группа по проведению референдума самостоятельно определяют содержание, формы и методы своей агитации, самостоятельно проводят ее, а также вправе в установленном законодательством порядке привлекать для ее проведения иных лиц. Это же положение дублируют и два других нормативных акта - «О выборах Президента Российской Федерации» и «О выборах депутатов Государственной Думы Федерального Собрания Российской Федерации». В соответствии с российским законодательством к формам и методам предвыборной агитации относятся: призывы голосовать за кандидата, кандидатов, список, списки кандидатов либо против него (них); выражение предпочтения какому-либо кандидату, избирательному объединению, в частности указание на то, за какого кандидата, за какой список кандидатов, за какое избирательное объединение будет голосовать избиратель; описание возможных последствий в случае, если тот или иной кандидат будет избран или не будет избран, тот или иной список кандидатов будет допущен или не будет допущен к распределению депутатских мандатов; распространение информации, в которой явно преобладают сведения о каком-либо кандидате (каких-либо кандидатах), избирательном объединении в сочетании с позитивными либо негативными комментариями; распространение информации о деятельности кандидата, не связанной с его профессиональной деятельностью или исполнением им своих служебных (должностных) обязанностей; деятельность, способствующая созданию положительного или отрицательного отношения избирателей к кандидату, избирательному объединению, выдвинувшему кандидата, список кандидатов» ${ }^{46}$. Становится очевидным, что политический PR в большем степени, чем

\footnotetext{
${ }^{46}$ Дюдина П.А. Политическая реклама: цели и средства (к проблеме конституционно-правового регулирования). // Конституционное и муниципальное право. - 2008. - №11. - С. 83.
} 
политическая реклама, соответствует содержанию политического маркетинга, поскольку предполагает выработку политической программы, формирующей имидж, ценностные характеристики и потребности отдельных политических акторов. Для более четкого понимания сущности политического маркетинга необходимо обратиться к иным смежным понятиям. В частности, политическим коммуникациям.

Политические коммуникации представляют собой процесс передачи информации о политике, политической организации, кандидате избирателям. Политические коммуникации, как правило, нацелены на ту часть избирателей (целевой аудитории), которая является для политического актора потенциально заинтересованным в его победе на выбоpax. Абсентеистически настроенные избиратели попадают в поле зрения коммуникационных каналов политических акторов. Зачастую политический актор не ориентирован на победу на выборах, поскольку и стремиться сформировать общественное мнение по определенному вопросу, тогда объектом его коммуникативного воздействия оказывается все сообщество в целом. Но для любой целевой аудитории всегда характерна способность - реагировать на коммуникационные вызовы политических акторов ${ }^{47}$.

Политические коммуникации оказываются эффективными только тогда, когда они имеют определенную цель, целевую аудиторию и каналы коммуникации. Политические коммуникационные вызовы не всегда носят планированный характер, зачастую становясь незапланированными. Непосредственно каналы коммуникации могут включать в себя рекламy, PR, пропаганду и др. Каждый канал предполагает использование определенных технологических приемов доведения информации до аудитории (спонсорство, митинги, фандрайзинг, перформансы и т.п. ${ }^{48} \mathrm{~B}$ случае если запланированная коммуникация дополняется незапланированной и противоречит целям политических акторов, то она отрицательно сказывается на результатах избирательной кампании. Совершенно обратная ситуация возникает в противоположном случае. Если цели коммуникации совпадают с целями избирательной кампании и у политического

${ }^{47}$ Грачев Г.В. Информационные технологии политической борьбы в российских условиях // Полис. - 2000. - № 3. - С. 153.

48 Наумова Е.В. Политический маркетинг в современной России как средство управления электоральным поведением граждан: Автореф. дис...к.полит.н. - М., 2002. - С. 14. актора есть данные о природе данной информации и способах управления ею. Процесс самоорганизации в политических коммуникациях является необходимым свойством политического процесса, поскольку позволяет выявить его новые потенциальные возможности. Но эффективность положительной стихийной коммуникации ограничена во времени, поскольку в период политической борьбы она может быть использована соперниками или полностью разрушена. Поскольку политический маркетинг представляет собой сложную систему, постольку в круг каналов коммуникации можно включить: встречи кандидата и его доверенных лиц с избирателями, митинги, реклама, связи с общественностью материальное стимулирование избирателей (бесплатные обеды, подарки, открытки, концерты и т.д. $)^{49}$

Процесс управления маркетинговой стратегией включает четыре этапа: оценка рыночных потребностей и возможностей, выбор целевых рынков, разработка комплекса маркетинговых воздействий и реализация стратегии и плана маркетинга.

На первом этапе собирают информацию о состоянии внешней среды, а также проводят анализ сильных и слабых сторон самой избирательной кампании (ситуационный анализ). Впоследствии составляют маркетинговый портрет целевой аудитории - выявляют признаки потенциальных потребителей, их потребности, мотивации, предпочтения целевой аудитории.

На втором этапе рынок сегментируется на основе полученных на первом этапе данных. На этом же этапе компания отбирает наиболее перспективные сегменты целевой аудитории и соответствующим образом позиционирует свой товар.

Приняв решение о концепции позиционирования товара (или услуги), политические акторы приступают к третьему этапу - разрабатывают комплекс маркетинговых воздействий для его продвижения посредством маркетинговых коммуникаций (реклама, стимулирование сбыта, формирование общественного мнения (public relations), пропаганда, личные продажи и т.д. $)^{50}$.

\footnotetext{
${ }^{49}$ Морозова Е. Г. Политический рынок и политический маркетинг: концепции, модели, технологии. М.: Российская политическая энциклопедия, 1998. - С. 93.

${ }^{50}$ Твердов A.A. Политический маркетинг: коммуникативное взаимодействие политической власти и общества: автореф. дисс...к.полит.н. - М., 2005. - С. 19.
} 


\section{Политика и общество 8 (116) • 2014}

Таким образом, становится очевидным, что политический маркетинг в рамках своих функций реализует следующие целевые установки: развивает концепцию коммуникации в зависимости от выдвинутых идей, определяет адекватность своих идей рынку, выявляет, какую позицию надо занять в зависимости от личностных качеств лидера, ожиданий рынка, наличия других претендентов ${ }^{51}$. Основу маркетинга составляет политические коммуникации, реализуемые через различные каналы, преимущественно сетевого назначения. Основополагающее значение в современном государстве приобретают публичные политические коммуникации. Публичные коммуникации представляют собой вид коммуникаций, нацеленных на передачу информации, затрагивающей общественный интерес, с одновременным приданием ей публичного статуса. Под публичным статусом мы понимаем статус, связанный с открытостью и с ориентацией на общее благо (общий интерес). Непубличная коммуникация имеет дело с информацией, у которой нет публичного статуса (приватные коммуникации, специализированные коммуникации, закрытые и секретные коммуникации и т.п.).

Проведенный анализ соотношения понятий «политическая реклама» и «PR» позволил прийти к выводу о том, что они выступают ключевыми механизмами политического маркетинга. Сходство данных дефиниций определяется маркетинговым информационным характером их деятельности, направленным на создание положительного образа с целью продажи политического продукта (товара). Данное обстоятельство позволяет их относить к диалоговым формам коммуникации, которые, в свою очередь, имеют не персональный характер обращения к массам потребителей. Однако политическая реклама и $\mathrm{PR}$ имеют ряд различий. Если политическая реклама относится к платной форме коммуникации, то PR - к бесплатной. Миссией рекламы выступает стимулирование сбыта, в то время как миссией PR - создание взаимопонимания между организацией и общественностью. В отношении информационного воздействия политическая реклама допускает идеализацию и недосказанность (сокрытие)

\footnotetext{
${ }^{51}$ Алтухова Н.Ю. Политический маркетинг в современной России: автореф. дис...канд. полит.наук. - Ставрополь, 2006. - C. 18.
}

фактов, в то время как PR нацелены на правдивую и полную информированность потребителей. Реклама чаще всего определяется краткосрочным характером деятельности политических институтов, a PR ориентированы на долгосрочную перспективу, долгосрочную взаимную ответственность сторон. Основными задачами политической рекламы является создание положительного образа кандидата или выявление негативных сторон и слабостей идеи, а задачи PR ориентированы на согласование целей всех участников взаимодействия. Реклама может носить как этический, так и неэтический характер, в то время как PR обязательно этичны. Эффективная политическая реклама направлена на увеличение деловых связей, привлечение сторонников, а эффективные политические PR - на получение правдивой информации и согласования интересов участников взаимодействия. Реклама ориентирована на потребителей, a PR - на общество. Исходя из применения методов воздействия, политическая реклама может быть агрессивной, a PR всегда доброжелательны. Выявленные особенности свидетельствуют о неограниченных особенностей данных механизмов политического маркетинга в политических коммуникациях демократического государства. Политический PR представляет собой особую технологию политического управления, систему двусторонней коммуникации между организациями и общественностью в целях достижения согласия всех акторов. Политический маркетинг ориентирован на реализацию принципов демократического управления, в том числе, и посредством использования PR технологий, но в целях продвижения товара (услуги, идеи, личности). Он видит необходимость изучения общественного мнения в целях формирования маркетинговой стратегии, а не выстраивания коммуникаций, основанных на взаимопонимании всех политических акторов.

Политический маркетинг как самостоятельная научная концепция и область исследования представляет собой совокупность форм, методов и технологий исследования, проектирования, регулирования и внедрения в общественно-политическую практику определенных установок общественного сознания с целью завоевания и удержания контроля за рынком власти. Ключевыми механизмами политических коммуни- 
каций в маркетинге выступают «политическая реклама» и «PR». Становясь частью коммуникативного процесса политического маркетинга, политическая реклама обладает собственными специфическими чертами. В зависимости от поставленных целей субъектом политического процесса выбираются способы и методы воздействия на общество, группы граждан, направленные на получение наиболее эффективного и оперативного результата. Несмотря на отождествление данных дефиниций в обыденной практике, с точки зрения политической науки их необходимо четко разделять на основе критериев содержания, целевой направленности и результативности. Практика российского политического маркетинга свидетельствует о необходимости перехода его из мобилизационного формата в модернизационный. Суть модернизационной парадигмы политического маркетинга заключается в стремлении гражданского общества активно участвовать в политических процессах, влиять на процесс принятия политических решений. Для этого граждане страны должны осознать необходимость защиты своих политических прав и стремиться их отстаивать.
Политический маркетинг институционализируется как деятельность по управлению процессом изучения и прогнозирования спроса на политический «товар», создания его новых видов в соответствии с требованиями и ожиданиями политического рынка, повышения привлекательности и успешного продвижения востребованного политического «товара» в электоральном пространстве, используя адекватные и эффективные политические технологии. К числу особенностей современного российского политического рынка относятся: несформированность (суженность) числа участников, сегментарность, однообразие или невнятность предлагаемых политических программ и альтернатив решения социально-значимых проблем. Региональная специфика политического маркетинга в государственном политическом управлении заключается в его слабой адаптированности к социально-политическим условиям регионов, ограниченности спектра используемых политико-маркетинговых технологий в условиях неразвитости гражданского общества, гражданской и политической культуры, которые делают политический маркетинг в современной России малоэффективным.

\section{Библиография:}

1. Алтухова Н.Ю. Политический маркетинг в современной России: диссертация на соиск.степ.к.полит.н. Ставрополь, 2006. $-180 \mathrm{c}$.

2. Алтухова Н.Ю. Политический маркетинг в современной России: автореф. дис...канд. полит.наук. - Ставрополь, 2006. -23 c.

3. Беклешов Д.В., Самусев В.П. Реклама - ее функции, цели и методы создания. - Киев: Реклама, 1974. - 105 с.

4. Блэк С. Паблик рилейшнз. Что это такое? - М.: Новости, 1990. -238 с.

5. Бурдье П. Социология политики / Пер. с фр.; сост., общ. ред. и предисл. Н.А. Шматко. M.: Socio-Logos, 1993. - 336 c.

6. Голубкова Е.Н. Маркетинговые коммуникации. - М.: Финпресс, 2000. - 256 с.

7. Грачев Г.В. Информационные технологии политической борьбы в российских условиях // Полис. - 2000. - № 3. C. $151-156$.

8. Гунаре М.Л. Политический маркетинг в избирательной кампании: Автореф. дис... к.полит.н. - M, $2001 .-23$ с.

9. Дилигентский Г.Г. О политическом рынке и рациональном выборе в российских условиях // Полис. - $2002 .-$ №2. - С. $105-107$.

10. Дюдина П.А. Политическая реклама: цели и средства (к проблеме конституционно-правового регулирования). // Конституционное и муниципальное право. - 2008. - №11. - С. 80 - 86.

11. Егорова-Гантман Е.В. Политическая реклама. - М.: Николло-Медиа, 2002. - 240 с.

12. Зазыкин В.Г. Психологические аспекты избирательного процесса. - М.: РЦОИТ, 2002.

13. Ильясов Ф.Н. Политический маркетинг, или Как «продать» вождя. // Полис. - 1997. - № 5. - С. 99 - 106.

14. Козлов С.В. Политический маркетинг: учебное пособие / С.В. Козлов. - Новосибирск: СибАГС, 2008. - 133 с.

15. Коттлер Ф. Основы маркетинга. - СПб.: Литера плюс, 1994.

16. Лазарфельд Г.А. Политология. - М.: Гардарики, 2006. - 588 с.

17. Лебедева Т. Паблик рилейшнз. Корпоративная и политическая режиссура. М.: Изд-во МГУ, $1999 .-350$ с.

18. Лисовский С.Ф. Политическая реклама [Электронный ресурс] / С.Ф. Лисовский. // [Режим доступа]: http://www. advesti.ru/publish/osn/200405_polit (Дата обращения: 01.08.2013) 


\section{Политика и общество 8 (116) • 2014}

19. Лисовский С.Ф., Евстафьев В.А. Избирательные технологии: история, теория, практика. М., $2007 .-320$ с.

20. Марченко Г. И. Политические консультанты в зеркале американской социологии // Социс. 2005. - №5. - С. 71 - 80.

21. Медеуова Д.Т. Общие подходы и специфика политического маркетинга / Д.Т. Медеуова. - М.: Институт научной информации по общественным наукам, 2010.

22. Морозова Е.Г. Политический рынок и политический маркетинг: Концепции, модели, технологии. М.: РОССПЭН, 1999. - $247 \mathrm{c}$.

23. Наумова Е.В. Политический маркетинг в современной России как средство управления электоральным поведением граждан: Автореф. дис...к.полит.н. - М., 2002. - 25 с.

24. Недяк И.Л. Политический маркетинг: Основы теории. М.: Весь мир, 2008. - 270 с.

25. Недяк И.Л. Актуальность применения метафоры политического маркетинга для изучения и прогнозирования политического процесса [Электронный ресурс] // [Режим доступа]: URL: http://www.strategy-spb.ru/partner/files/nedyak. pdf (Дата обращения: 02.08.2013)

26. Нежданов Д. В. Политический маркетинг: вчера, сегодня, завтра. СПб.: Питер, 2004. - 160 с.

27. Покрищук Д.В. Политический маркетинг: к вопросу о некоторых аспектах российского и зарубежного опыта // Журнал научных публикаций аспирантов и докторантов. - 2008. - № 10.

28. Политологический словарь. / Под ред. проф. В.Ф. Халипова. - М.: Высшая школа, 1995.

29. Пшизова С. И. Демократия и политический рынок в сравнительной перспективе // Полис. 2000. - №2. - С. 30 - 44 .

30. Реклама за рубежом. Пер. с англ. - М.: Прогресс, 1977. - 371 с.

31. Скрипюк И.И. Политическая реклама и политические PR в России // Общество и политика: Современные исследования, поиск концепций / Под ред. В.Ю. Большакова. - СПб., 2000.

32. Стровский Д.А. Реклама и паблик рилейшнз: Словарь английских терминов. - Екатеринбург: Урал. гос. тех. университет, 1999. - 208 с.

33. Твердов А.А. Политический маркетинг: коммуникативное взаимодействие политической власти и общества: автореф. дисс...к.полит.н. - М., 2005. -24 с.

34. Технология и организация выборных кампаний: зарубежный и отечественный опыт. М.: Луч, $1995 .-320$ с.

35. Тучков С.М. К вопросу о законодательном регулировании некоторых аспектов применения технологий «паблик рилейшнз» в государственном управлении и политических кампаниях // Вестник МГУ. - Сер. 12. - 2001. № 4. - С. $32-40$.

36. Феофанов О.А. Реклама: новые технологии в России. - СПб.: Питер, 2000. - 384 с.

37. Фурман Д., Морозов А., Коргунюк Ю., Блюм А. Политическая система России после путинских реформ [Электронный ресурс] // [Режим доступа]: URL: http://www.polit.ru/research/2005/01/27/ polit_system.html (Дата обращения: 01.08.2013)

38. Чумиков А.Н., Бочаров М.П. Связи с общественностью: теория и практика. М.: Дело, 2006. - 552 с.

39. Bongrand M. Le marketing politique. - Paris, 1986. $-280 \mathrm{p}$.

40. Crouch C. Post-democracy / C. Crouch [Электронный ресурс] // [Режим доступа]: URL: http://ww.kreisky-forum.org/ pdfs/2009/2009_03_05.pdf (Дата обращения: 24.09.2012).

41. Hennenberg S. Political Marketing Theory: Hendiadyoin or Oxymoron // Working Paper Series, University of Bath, 2004.

42. Kotler Ph. Marketing for Non-Profit Organisations. - Englewood Cliffs, 1975. - 340 p.

43. Lindon D., Weill P. Le choix d'un depute. Un modele explicatif du cornportement electoral. - Paris, 1974.

44. Lipman M. Media Manipulation and Political Control in Russia [Электронный ресурс] // [Режим доступа]: URL: http://www.chathamhouse.org.uk/publications/papers/view/-/id/698/ (Дата обращения: 03.08.2013).

45. Mauser G. Political Marketing: an approach to campaign strategy / Gary A. Mauser Praeger New York, 1983. - 236 p.

46. Markus Karp, Udo Zolleis Politisches Markting: eine Einfuhrung in das Politisches Marktingmit aktuellen Bezugen aus Wissenschaft und Praxis. Baden-Baden. 2004. - 278p.

47. Nimmo D. The Political Persuaders. - Englewood Cliffs, 1965. - 612 p.

48. Ragsdale L. Strong feelings: emotional responsness to presidents. // Political Behavior. - V. 13. - № 1. - 1991. - P. $33-59$.

49. Борисенков А.А. Особенности политического развития // NB: Философские исследования. - 2013. - 6. - C. $171-$ 198. DOI: 10.7256/2306-0174.2013.6.445. URL: http://www.e-notabene.ru/fr/article_445.html

50. Розин В.М. К пониманию оснований общественно-политического дискурса // NB: Философские исследования. 2013. - 4. - C. 30 - 52. DOI: 10.7256/2306-0174.2013.4.380. URL: http://www.e-notabene.ru/fr/article_380.html

\section{References (transliteration):}

1. Altukhova N.Yu. Politicheskii marketing v sovremennoi Rossii: dissertatsiya na soisk.step.k.polit.n. Stavropol', 2006. $180 \mathrm{~s}$.

2. Altukhova N.Yu. Politicheskii marketing v sovremennoi Rossii: avtoref. dis...kand. polit.nauk. - Stavropol', 2006. - 23 s. 
3. Bekleshov D.V., Samusev V.P. Reklama - ee funktsii, tseli i metody sozdaniya. - Kiev: Reklama, 1974. - 105 s.

4. Blek S. Pablik rileishnz. Chto eto takoe? - M.: Novosti, 1990. - $238 \mathrm{~s}$.

5. Burd'e P. Sotsiologiya politiki / Per. s fr.; sost., obshch. red. i predisl. N.A. Shmatko. M.: Socio-Logos, $1993 .-336$ s.

6. Golubkova E.N. Marketingovye kommunikatsii. - M.: Finpress, 2000. - 256 s.

7. Grachev G.V. Informatsionnye tekhnologii politicheskoi bor’by v rossiiskikh usloviyakh // Polis. - 2000. - № 3. - S. 151 $-156$.

8. Gunare M.L. Politicheskii marketing v izbiratel'noi kampanii: Avtoref. dis... k.polit.n. - M, 2001. - 23 s.

9. Diligentskii G.G. O politicheskom rynke i ratsional’nom vybore v rossiiskikh usloviyakh // Polis. - 2002. - №2. - S. 105 $-107$.

10. Dyudina P.A. Politicheskaya reklama: tseli i sredstva (k probleme konstitutsionno-pravovogo regulirovaniya). // Konstitutsionnoe i munitsipal'noe pravo. - 2008. - №11. - S. $80-86$.

11. Egorova-Gantman E.V. Politicheskaya reklama. - M.: Nikollo-Media, 2002. - $240 \mathrm{~s}$.

12. Zazykin V.G. Psikhologicheskie aspekty izbiratel'nogo protsessa. - M.: RTsOIT, 2002.

13. Il'yasov F.N. Politicheskii marketing, ili Kak «prodat'» vozhdya. // Polis. - 1997. - № 5. - S. 99 - 106.

14. Kozlov S.V. Politicheskii marketing: uchebnoe posobie / S.V. Kozlov. - Novosibirsk: SibAGS, $2008 .-133$ s.

15. Kottler F. Osnovy marketinga. - SPb.: Litera plyus, 1994.

16. Lazarfel'd G.A. Politologiya. - M.: Gardariki, 2006. - 588 s.

17. Lebedeva T. Pablik rileishnz. Korporativnaya i politicheskaya rezhissura. M.: Izd-vo MGU, 1999. - $350 \mathrm{~s}$.

18. Lisovskii S.F. Politicheskaya reklama [Elektronnyi resurs] / S.F. Lisovskii. // [Rezhim dostupa]: http://www.advesti.ru/ publish/osn/200405_polit (Data obrashcheniya: 01.08.2013)

19. Lisovskii S.F., Evstaf'ev V.A. Izbiratel'nye tekhnologii: istoriya, teoriya, praktika. M., 2007. - $320 \mathrm{~s}$.

20. Marchenko G. I. Politicheskie konsul’tanty v zerkale amerikanskoi sotsiologii // Sotsis. 2005. - №5. - S. $71-80$.

21. Medeuova D.T. Obshchie podkhody i spetsifika politicheskogo marketinga / D.T. Medeuova. - M.: Institut nauchnoi informatsii po obshchestvennym naukam, 2010.

22. Morozova E.G. Politicheskii rynok i politicheskii marketing: Kontseptsii, modeli, tekhnologii. M.: ROSSPEN, 1999. - 247 s.

23. Naumova E.V. Politicheskii marketing v sovremennoi Rossii kak sredstvo upravleniya elektoral'nym povedeniem grazhdan: Avtoref. dis...k.polit.n. - M., 2002. - 25 s.

24. Nedyak I.L. Politicheskii marketing: Osnovy teorii. M.: Ves' mir, 2008. - 270 s.

25. Nedyak I.L. Aktual'nost' primeneniya metafory politicheskogo marketinga dlya izucheniya i prognozirovaniya politicheskogo protsessa [Elektronnyi resurs] // [Rezhim dostupa]: URL: http://www.strategy-spb.ru/partner/files/nedyak.pdf (Data obrashcheniya: 02.08.2013)

26. Nezhdanov D. V. Politicheskii marketing: vchera, segodnya, zavtra. SPb.: Piter, 2004. - $160 \mathrm{~s}$.

27. Pokrishchuk D.V. Politicheskii marketing: k voprosu o nekotorykh aspektakh rossiiskogo i zarubezhnogo opyta // Zhurnal nauchnykh publikatsii aspirantov i doktorantov. - 2008. - № 10.

28. Pshizova S. I. Demokratiya i politicheskii rynok v sravnitel’noi perspektive // Polis. 2000. - №2. - S. 30 - 44.

29. Skripyuk I.I. Politicheskaya reklama i politicheskie PR v Rossii // Obshchestvo i politika: Sovremennye issledovaniya, poisk kontseptsii / Pod red. V.Yu. Bol'shakova. - SPb., 2000.

30. Strovskii D.A. Reklama i pablik rileishnz: Slovar' angliiskikh terminov. - Ekaterinburg: Ural. gos. tekh. universitet, 1999. $-208 \mathrm{~s}$.

31. Tverdov A.A. Politicheskii marketing: kommunikativnoe vzaimodeistvie politicheskoi vlasti i obshchestva: avtoref. diss... k.polit.n. - M., 2005. - 24 s.

32. Tuchkov S.M. K voprosu o zakonodatel'nom regulirovanii nekotorykh aspektov primeneniya tekhnologii «pablik rileishnz» v gosudarstvennom upravlenii i politicheskikh kampaniyakh // Vestnik MGU. - Ser. 12. - 2001. № 4. - S. 32 - 40.

33. Feofanov O.A. Reklama: novye tekhnologii v Rossii. - SPb.: Piter, 2000. - 384 s.

34. Furman D., Morozov A., Korgunyuk Yu., Blyum A. Politicheskaya sistema Rossii posle putinskikh reform [Elektronnyi resurs] // [Rezhim dostupa]: URL: http://www.polit.ru/research/2005/01/27/ polit_system.html (Data obrashcheniya: 01.08.2013)

35. Chumikov A.N., Bocharov M.P. Svyazi s obshchestvennost'yu: teoriya i praktika. M.: Delo, 2006. - 552 s.

36. Bongrand M. Le marketing politique. - Paris, 1986. $-280 \mathrm{r}$.

37. Crouch C. Post-democracy / C. Crouch [Elektronnyi resurs] // [Rezhim dostupa]: URL: http://ww.kreisky-forum.org/ pdfs/2009/2009_03_05.pdf(Data obrashcheniya: 24.09.2012).

38. Hennenberg S. Political Marketing Theory: Hendiadyoin or Oxymoron // Working Paper Series, University of Bath, 2004.

39. Kotler Ph. Marketing for Non-Profit Organisations. - Englewood Cliffs, 1975. - 340 r.

40. Lindon D., Weill P. Le choix d'un depute. Un modele explicatif du cornportement electoral. - Paris, 1974.

41. Lipman M. Media Manipulation and Political Control in Russia [Elektronnyi resurs] // [Rezhim dostupa]: URL: http:// www.chathamhouse.org.uk/publications/papers/view/-/id/698/ (Data obrashcheniya: 03.08.2013). 


\section{Политика и общество $8(116) \cdot 2014$}

42. Mauser G. Political Marketing: an approach to campaign strategy / Gary A. Mauser Praeger New York, 1983. - 236 r.

43. Markus Karp, Udo Zolleis Politisches Markting: eine Einfuhrung in das Politisches Marktingmit aktuellen Bezugen aus Wissenschaft und Praxis. Baden-Baden. 2004. - 278r.

44. Nimmo D. The Political Persuaders. - Englewood Cliffs, 1965. - 612 r.

45. Ragsdale L. Strong feelings: emotional responsness to presidents. // Political Behavior. - V. 13. - № 1. - 1991. - R. 33 - 59.

46. Borisenkov A.A. Osobennosti politicheskogo razvitiya // NB: Filosofskie issledovaniya. - 2013. - 6. - C. 171 - 198. DOI: 10.7256/2306-0174.2013.6.445. URL: http://www.e-notabene.ru/fr/article_445.html

47. Rozin V.M. K ponimaniyu osnovanii obshchestvenno-politicheskogo diskursa // NB: Filosofskie issledovaniya. - 2013. 4. - C. 30 - 52. DOI: 10.7256/2306-0174.2013.4.380. URL: http://www.e-notabene.ru/fr/article_380.html 